\title{
REVIEW
}

\section{From coral reefs to whale teeth: estimating mortality from natural accumulations of skeletal materials}

\author{
Vladimir V. Laptikhovsky ${ }^{1, *}$, Christopher J. Barrett ${ }^{1}$, Philip R. Hollyman ${ }^{2}$ \\ ${ }^{1}$ Centre for Environment, Fisheries and Aquaculture Science (CEFAS), Pakefield Road, Lowestoft, Suffolk NR33 0HT, UK \\ ${ }^{2}$ School of Ocean Sciences, College of Natural Sciences, Bangor University, Menai Bridge, Anglesey LL59 5AB, UK
}

\begin{abstract}
Estimation of natural and anthropogenic (fishing, hunting) mortality is the key problem in studies of population dynamics. Numerous theoretical approaches were developed in environmental sciences to find a solution based on information that could be obtained from live representatives of populations of interest. We review the alternative methods used by marine biologists, palaeontologists and zoo-archaeologists to estimate natural and anthropogenic mortality from age-registering structures of the different taxa (corals, molluscs, fishes and mammals) collected in thanatocoenoses and containing information about the exact individual age-at-death. Not all approaches and techniques are transferrable from one field to another because they were elaborated for organisms with different morphologies and ecologies, but cross-fertilisation of ideas presented in this review might provide a new insight into studies related to population dynamics.
\end{abstract}

KEY WORDS: Age-registering structures - Mortality ' Mollusc • Coral reef - Fish • Marine mammals

\section{INTRODUCTION}

The estimation of mortality and its ontogenetic changes in a given population is a crucial metric for understanding the population's dynamics. Mortality is an external force that shapes life histories and other traits through natural selection depending on the impact of different biotic and abiotic factors and is also an outcome of these life histories (Jørgensen \& Holt 2013). For human-targeted species like commercial invertebrates and vertebrates, the total mortality $(Z)$ arises from 2 sources: natural mortality $(M)$ which can be attributed to several factors such as senescence, predation, density and size (Barbeau et al. 1994, Brocken \& Kenchington 1999, Andresen et al. 2014) and anthropogenic mortality, which often arises as a direct or indirect result of fisheries ac-

${ }^{*}$ Corresponding author: vladimir.laptikhovsky@cefas.co.uk

$\S$ Advance View was available online October 23, 2017 tivities ('fishing mortality' in marine ecosystems: $F_{\text {; }}$ Gosling 2004).

Anthropogenic mortality and particularly fishing mortality can be very important and even exceed twice the natural mortality in some fish populations without causing a stock to collapse (Jennings et al. 2001). Even a small variation in $F$ and $M$ will cause a stock to increase or decrease, bloom or disappear. Knowledge of mortality rates and their historical changes might have a wide application in studies of evolution (comparing species-specific life strategies), fisheries management (as required by every population model), population demography (variability due to historical environmental changes and human activities) and human demography (social and cultural impact).

Natural mortality is one of the most difficult and critical elements of a stock assessment (Hewitt et al.

() The authors 2018. Open Access under Creative Commons by Attribution Licence. Use, distribution and reproduction are unrestricted. Authors and original publication must be credited. 
2007), and the problem of its estimation persists among different commercial marine taxa. Significant scientific effort has been invested into quantifying this variable and elusive parameter using innumerable statistical approaches, based on assumptions about its relation to some features of life histories such as age structure of catches, maximum observed age and growth rates (e.g. Gunderson \& Dygert 1988, Quinn \& Deriso 1999, Hewitt \& Hoenig 2005, Hewitt et al. 2007, Gislason et al. 2008). Another approach consists of observation of effects of actual mortality in situ and includes numerous methods to assess rates of the gradual decrease in numbers of known individual invertebrates, fish, seabirds and marine mammals that were either tagged or visually identifiable (e.g. Cormack 1964, Krebs 1999, Best \& Kishino 1998, Lettink \& Armstrong 2003).

This article summarises methodologies of a third approach for studying mortality in natural habitats: the use of directly observed or estimated data on individual age-at-death $(A D)$ using naturally accumulated skeletal materials in thanatocoenoses or 'death assemblages'. A thanatocoenosis is an assemblage of fossils that occurred together in a given area at a given moment of historical/geological time which in some instances may not have been associated during life but were brought together after death by some process (e.g. water currents or predator activity) (Hallam 1967, Aller 1995). This final event (i.e. death) in the life of every creature can be recorded in annual (in some taxa, daily) growth rings embossed in statoliths, otoliths, shells, beaks, scales, vertebrae, eye crystals, spines, bones, whale earplugs and other age-registering structures (AReS) among members of the animal kingdom as well as on tombstones and in books of records from ancient human civilisations to the present day.

This approach requires neither best choice of the theoretical model nor long-term observation of the actual process in the wild. Considering that agereading methods are highly specific for different taxa of the animal kingdom, we group existing methodologies respectively.

\section{CORALS}

\section{Collection data on age-at-death}

Mortality in all living things (no living thing is immortal) can be distinguished between natural, such as predation and old age, and anthropogenic (e.g. fishing, hunting or murder). Corals, however, are also subjected to a third category: partial mortality, in which a part of a colony may die but the remaining polyps may still be functional. A single coral colony appears to have a quality similar to the Schrödinger's cat paradox: it can be subjected to individual deaths but the colony still remains alive. Total (natural and anthropogenic) and partial mortalities play different ecological roles and can be assessed differently using $A D$, for which, the coral skeleton itself can be used to estimate age via a range of methods.

Scleractinian stony corals grow isometrically (Chadwick-Furman et al. 2000), presenting annual growth rings, forming in the direction of growth as skeletal density bands (Knutson et al. 1972). However, partial mortality makes determining life-history parameters of such corals (particularly scleractinians) difficult, especially when combined with other factors such as fragmentation and fusion, which often means that corals of a similar size can be of different ages (Caroselli et al. 2012). Because corals are sessile, colonising where they settle as larvae, it is therefore relatively easy to sample their population-specific age structure, particularly when the time of initial colony settling is exactly known, as in the case of shipwrecks (Wendt et al. 1989). Applying ageing techniques can help increase the certainty of the extents of coral species' natural mortalities in response to various disturbances, and as such, coral reef status (Glassom et al. 2004).

The following methods can be considered the most commonly used in dead coral ageing. It should be noted that whilst many case-studies exist which describe how observed $A D$ data are collected and interpreted, their applications may suit some coral colonies, but not others; amalgamating their methods could be used to reconstruct natural mortality for population demographic use.

\section{Growth-band analysis}

As previously described (Knutson et al. 1972, Chadwick-Furman et al. 2000), corals such as scleractinians and gorgonians present annual growth rings, which can be used to age specimens relatively easily (Logan \& Anderson 1991, Goffredo \& Lasker 2006). The reliability of growth-band analysis, however, relies on individuals which rarely fuse and/or fragment and where growth-pattern anomalies can detect partial mortality (Babcock 1991, ChadwickFurman et al. 2000, Caroselli et al. 2012). Where this analysis is appropriate, subsequent age-based population dynamic models make it possible to further determine demographic characteristics; Goffredo \& 
Lasker (2008) successfully produced an age-based Beverton-Holt model from data on the Caribbean gorgonian coral Pseudopterogorgia elisabethae.

Whilst age structure and growth of many coral species may be comprehensively described, some smaller, more cryptic species are less studied, and whether their growth rates differ in different environmental conditions may not be certain (ChadwickFurman et al. 2000). Per studies by Hughes \& Jackson (1985) and Bak \& Meesters (1998), most corals grow indeterminately and thus can have no true $\mathrm{L}_{\infty}$ (average length of an infinitely ageing specimen). This assumption does not apply to all species, however; Chadwick-Furman et al. (2000) noted isometric growth in stony corals such as Fungia granulosa, though colonial virtual growth cessation occurred between 30 and $40 \mathrm{yr}$ old, with $\mathrm{L} \infty$ assumed at $118 \mathrm{~mm}$. Chadwick-Furman et al. (2000) suggested that specimens may cease growth at this size to avoid sinking into soft sediment, though it may be possible that the species grow to larger sizes in areas of more stable ground types. In their study, skeletons of dead polyps were dried at $400^{\circ} \mathrm{C}$ for $24 \mathrm{~h}$. Then, the circular rings externally visible on the skeleton's aboral surface were counted and it was found (by the negative correlation between the frequency of individuals in age classes against coral age) that mortality rates were high when the corals were young. However they noted that if corals were still ageing despite reaching $\mathrm{L} \infty$, this ageing would not be identifiable via density ring analysis. Further related to size, GoodbodyGringley et al. (2015) report that it is possible to correlate coral colony surface area to age, provided partial mortality is low. This has proven a particularly appropriate method for giant, non-branching species such as Montastraea cavernosa, the great star coral. Once an age/size structure is assessed, it is then possible to estimate mortality as either partial or complete (such as from bleaching), which can further be used in comparative population studies (Meesters et al. 1996, Caroselli et al. 2012).

\section{Uranium-thorium (U-Th) method}

U-Th dating was used by Roff et al. (2015) to calculate the age of 'young' (<100 yr) boulder star coral Orbicella annularis to a 1 to 2 yr accuracy using lateral sectioning. Combining U-Th analysis with computed tomography analysis made it possible to identify the coral's rate of growth and $A D$, following parrotfish foraging, the dominant cause of bioerosion in Glovers Reef, Belize.

\section{X-radiography method}

Zhao et al. (2014) describe the monitoring of the massive coral Porites lutea in response to severe anthropogenic stresses. The collected cores were sectioned into slabs which, once dried and X-rayed, displayed their growth bands. The coral's age was then calculated from the sum of the colony's maximum length, weight and height, divided by 3 times the mean linear growth rate determined by the X-ray analysis. These results were used to reconstruct the age structure of parts of a reef that in theory also provides the possibility to estimate the natural mortality. However, mortality estimations were difficult because the reef had initially declined by $>80 \%$ since the 1980s and was gradually recovering after the introduction of a marine reserve in the 1990s; therefore, age structure, mortality and recruitment were not stable (Zhao et al. 2014).

\section{Ultra-violet light method}

Supriharyono (2004) examined the same coral species as Zhao et al. (2014) but also examined the effectiveness of UV light as an ageing technique. Once coral slabs were cut, fluorescent bands were revealed under black, $350 \mathrm{~nm}$ UV light, believed to be due to fulvic and humic acid concentrations which were elevated during Indonesia's wet season. However, not all density bands fluoresced under the light, and the author suggested that radiography was the more reliable ageing method for reconstruction of the age structure of the population.

\section{MOLLUSCS}

\section{Collection data on age-at-death}

Due to the diverse nature of the Mollusca, there are certain species groups for which $A D$ and $M$ are easier to determine. Estimates calculated for bivalves and gastropods are based on calcium carbonate shells which can endure in the environment after death. Dead shells can be utilized in a variety of ways to evaluate natural mortality for a given population. Much like living animals, they can be assessed using both length frequency analysis and direct ageing (e.g. Harzhauser et al. 2016).

The most common method for the estimation of $A D$ in bivalve populations utilizes shells from recently deceased animals. The collection of dead bivalve 
shells from thanatocoenoses can in some cases add a timeframe to the mortality itself. The use of articulated dead valves known as 'cluckers' or 'boxes' can allow the estimation of a time window in which the mortality occurred. With these valves, knowledge of the timing of hinge ligament decomposition (e.g. for oysters - Christmas et al. 1981; scallops - Dickie 1955, Orensanz et al. 1991; and mussels - Ciocco 1996) can allow scientists to assume that the shells are from recently deceased animals. An accurate estimation of hinge ligament decomposition is essential for this analysis because an underestimation will increase the value of $M$ (Orensanz et al. 1991, Gosling 2004).

During sampling, both the live and dead (still articulated) shells of a bivalve population can be collected, and estimates of $M$ can then be made by comparing the size-frequency distributions of both the live and dead animals. Possible errors in this method, and size frequency estimations in general, arise from the incorrect classification of animals to year cohorts (discussed by Mann et al. 2009). For some animals with easily discernible exterior age bands, such as scallops, shells can be directly aged for an estimate of the month of mortality (Merrill \& Posgay 1964, Caddy 1989) to give an estimate of the total deaths since the formation of the last growth ring. Articulated shells have been successfully utilized for several commercially important bivalve groups, including scallops (Ciocco 1996), mussels (e.g. Morsan \& Zaidman 2008) and oysters (Volstad et al. 2008, Mann et al. 2009). This method has also been used to estimate incidental fishery mortality by McLoughlin et al. (1991) who tracked the abundances of live, dead and damaged scallops Pecten fumatus throughout a season.

There are several potential problems with the use of articulated shells. For example, Cadée (2002) showed that through the process of death and decomposition, still articulated shells of Spisula subtruncata had floated up to $20 \mathrm{~km}$ away from their original population; however, this is unlikely to affect larger animals with heavier shells or reef-building bivalves. Discordance between shell composition in live and death assemblages was higher on narrow steep shelves than on broad flat shelves, suggesting that down-slope post-mortem transport might be a contributing factor in between-habitat transport of shells
(Kidwell 2013). There is also a possibility that in fished areas, articulated shells are broken up by bottom fishing practices (Gosling 2004). Naidu (1988) reported that the abundance of articulated dead shells was higher on fished ground than unfished, concluding that the increase seen on harvested grounds was due to incidental fishing damage which could potentially skew estimates of $M$. Hermit crabs also could carry empty gastropod shells to some distance from their actual habitat and so can potentially alter the molluscan shell death assemblages (Walker 1988), a problem that might be particularly important in palaeontology where studied surfaces are measured by dozens and hundreds of square metres.

Among extinct cephalopods, belemnites are a taxonomic group found in large numbers within fossil deposits and providing abundant material for studies. Direct ageing of belemnite rostra is possible following a study by Wierzbowski \& Joachimski (2009), who validated the daily periodicity of visible growth striations using a range of geochemical analyses (such as stable isotope and electron microprobe analysis; Fig. 1). These growth striations have been further used to determine life span and growth rates of fossilized belemnites (Wierzbowski 2013) and could potentially be utilized for the analysis of population structure and thus, natural mortality as in modern coleoids in which growth marks on statoliths and gladii also are deposited on the daily basis. Belemnite statoliths also bore supposedly daily growth

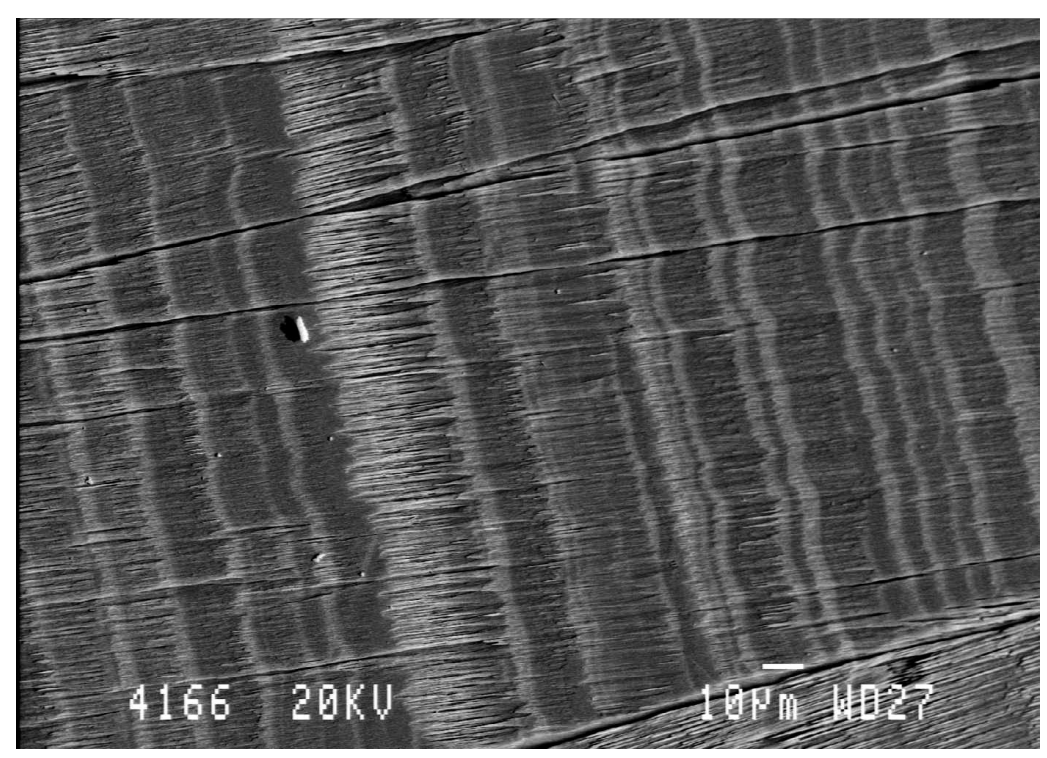

Fig. 1. Scanning electron photomicrograph of an etched $(6 \mathrm{~h}, 25 \%$ glutaraldehyde) rostral cross section of a fossilized Hibolithes hastatus belemnite with clearly visible daily growth lines (Wierzbowski \& Joachimski 2009). Reproduced with permission from H. Wierzbowski and GeoScienceWorld 
rings (Hart et al. 2015), but their actual periodicity was never validated.

Gastropods comprise a single shell with no ligament with which to track decomposition; instead, the potential burial time was used as a timeframe (ParsonsHubbard et al. 1999) for the ratio between dead and live shells in random samples by a towed gear (Laptikhovsky et al. 2016). Because the shells of Buccinum undatum contain no discernible annual growth rings, the age structure of the living whelk population from the same area was used as a proxy for estimation of $A D$ using age-length keys, determined through the analysis of annual striae on the operculum (Santarelli \& Gros 1985). The combination of population age structures of living $B$. undatum and dead shells then allowed the estimation of mortality (Fig. 2). Through the application of this technique which is normally reserved for bivalve populations, the key problem of natural mortality estimation may be answered for this commercially important gastropod species.

\section{Analysis of natural death assemblages (natural mortality)}

Shell death assemblages are often found within sea bed sediments which contain a grouping of species that may not represent living communities (Poirier et al. 2010). They are often the precursors to fossil assemblages (Boucot 1953, Kidwell 2013) and contain shells, the age of which could be identified by counting growth marks on the shell (Fig. 3).

Among molluscs, these assemblages have been used to estimate mortality of bivalve species. By collecting and analysing shells, it is possible to calculate the natural mortality of a molluscan population using size frequency analysis (Hallam 1967, Aller 1995). The population structure of the dead bivalve shells can also be compared to the living populations in the same locality to test the reliability of the estimates calculated (Aller 1995, Kidwell \& Rothfus 2010). Yanes et al. (2012) used a combination of predator drilling marks (indicating mortality through gastropod predation) and stable oxygen isotope analysis of the shell margin (the most recently formed shell material) to calculate the predation-related mortality and also a seasonal estimation of the mortality which supported increased predation rates seen in the field during summer months (Rilov et al. 2001, Quijón et al. 2007). Specific types of predation-related mortality can often be investigated using this method when the characteristic bore holes of predatory gastropods can be identified on the dead shells (e.g. Aller 1995,
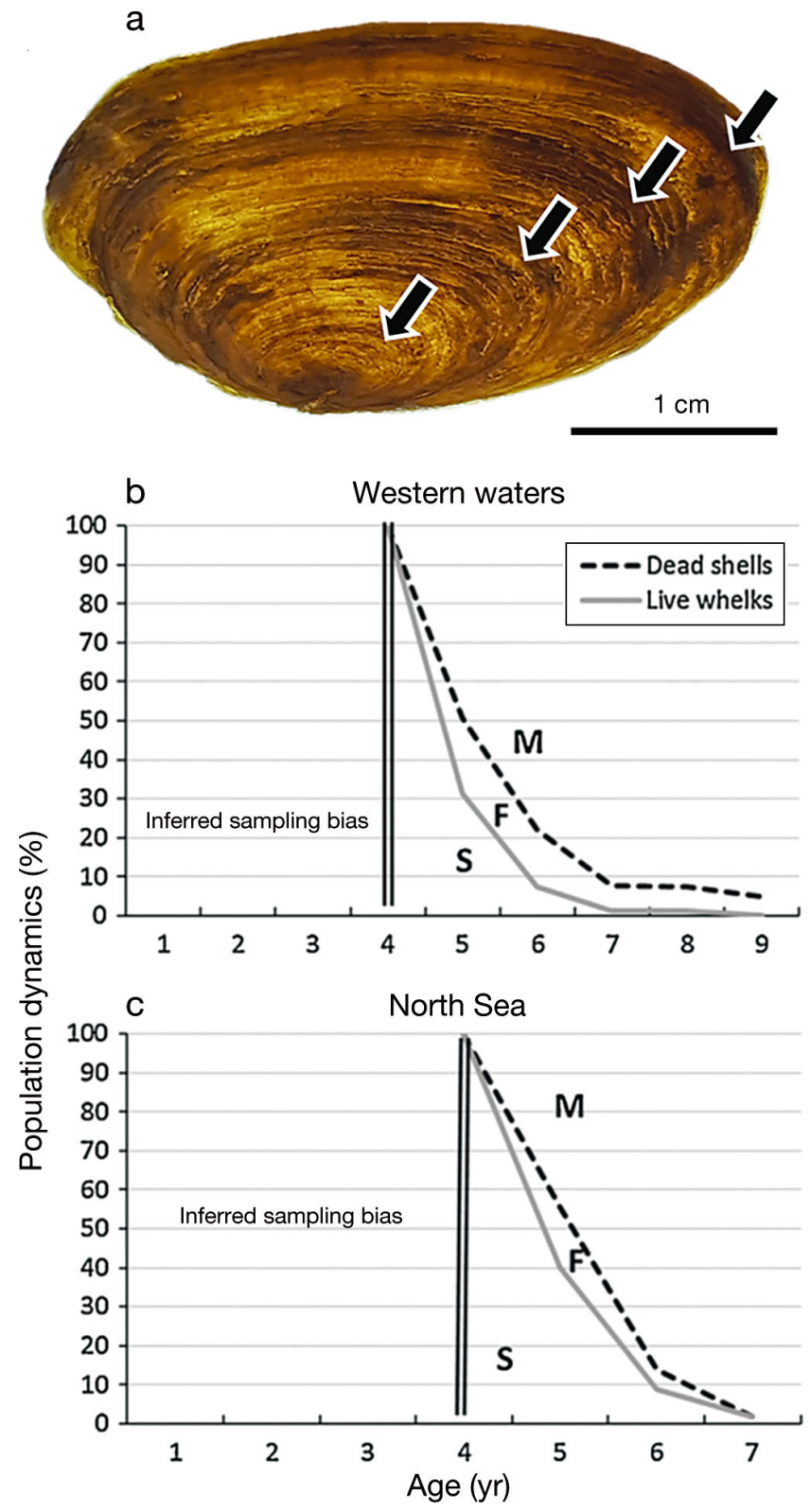

Fig. 2. (a) Tentative annual growth rings present on the surface of a Buccinum undatum operculum, validated by Santarelli \& Gros (1985, black arrows). (b,c) changes in whelk numbers with ageing as shown by size-frequencies of dead shells and live whelks. M: natural mortality; F: fisheries mortality; S: survival. Double line shows age of $4 \mathrm{yr}$ after which, whelks of ca. $70 \mathrm{~mm}$ shell height are supposed to be unselectively collected by fishing gears of $40 \mathrm{~mm}$ mesh size (Laptikhovsky et al. 2016). b \& c are reproduced with permission from the Elsevier Publishing Group

Weissberger \& Grassle 2003) and combined with known size-at-age.

Population structures (and therefore mortality estimates) are often difficult to discern from fossil shell assemblages because these are usually repre- 


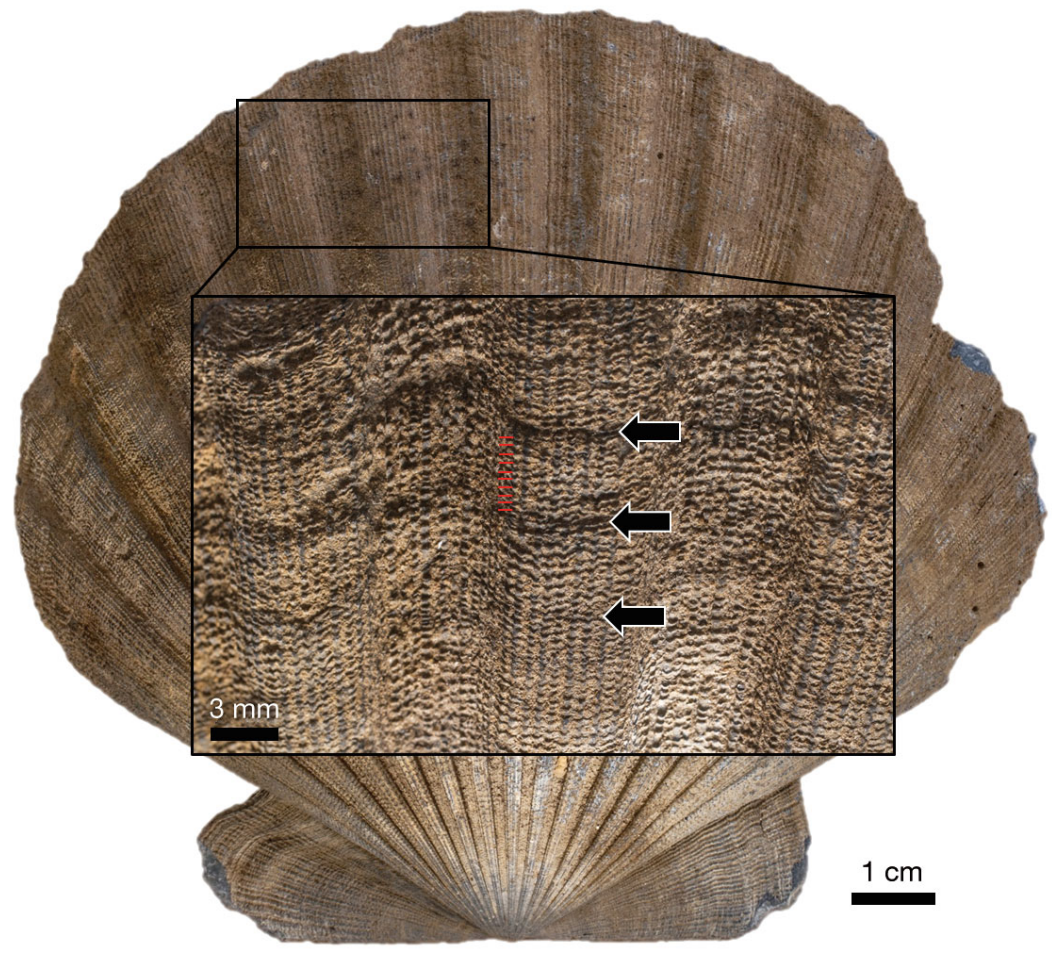

Fig. 3. Annual growth rings (black arrows) on the shell of Chesapecten (?)madisonius. Pliocene. Gloucester point, Yorktown, Virginia (photo: D. Roberts)

crab impact, and the commercial harvest being processed onshore so that no empty shells are returned to the environment to be potentially confused with those that died from natural causes. Dead shells also should be destroyed or buried in sediments within a few years to minimise the impact of time-averaging, the effect of which could be very important in ecosystems subjected to commercial fisheries.

\section{Analysis of shell middens (fishing mortality)}

Shell middens are archaeological collections formed from anthropogenic discards (Andrus 2011). Like naturally occurring fossil shell deposits, the contents of a shell midden are almost always time-averaged (Koppel et al. 2016), making population structure analysis difficult. Unlike fossil shell deposits, however, middens

sentative of a large time period which is averaged into a single deposit (Kidwell 1986, 1991). However, this issue can be avoided if it is proven that the fossil deposit represents a single time point in a population, such as an oyster reef (e.g. Chinzei 2013). Harzhauser et al. (2016) presented population data from such a preserved reef of the giant oyster Crassostrea gryphoides. The authors utilised laser scanning and photographic analysis to count and measure the shells within the deposit (Fig. 4) and then employed length frequency analysis of the shell sizes to calculate several population dynamic parameters such as natural mortality. A size-at-age key had already been described for this species through the stable oxygen isotope analysis of shells from the same fossil deposit (Harzhauser et al. 2011).

When the age structure of dead shells from recent thanatocoenoses is available simultaneously with that of live molluscs, both $F$ and $M$ can be estimated together. It is possible that if the age structure of live molluscs reflects total mortality, and distribution of $A D$-natural mortality, the difference can be accounted for by fishing mortality (Laptikhovsky et al. 2016). This approach requires a species that does not immigrate and emigrate to and from the studied area, which should be large enough to ignore hermit potentially represent unique repositories of information regarding ancient fishery related mortality. There are several techniques used for age analysis of shell middens (see below) that may lend themselves to mortality estimation of the shell populations contained within.

Providing the age of the deposits is known with some confidence (see 'Time-averaging and thanatocoenoses dating'), the composition of the middens can be investigated. As well as standard cohort and length frequency analyses of population structures (Caddy 1989, Mannino \& Thomas 2002), analysis of stable oxygen isotopes from the most recently formed shell section can be applied to determine the season of collection and to give a timeframe to mortality (Mannino et al. 2003, Burchell et al. 2013). As with the shells of live collected bivalves, sclerochronological techniques such as direct ageing of shells can also be employed on midden samples to extract a wealth of information regarding historical ecological and environmental conditions (see Andrus 2011 for review). A combination of these techniques could make middens a powerful tool in calculating historical fishery related mortality, which can also give important insight into the changes in foraging habits over the timeframe of human evolution (Klein \& Bird 2016). 

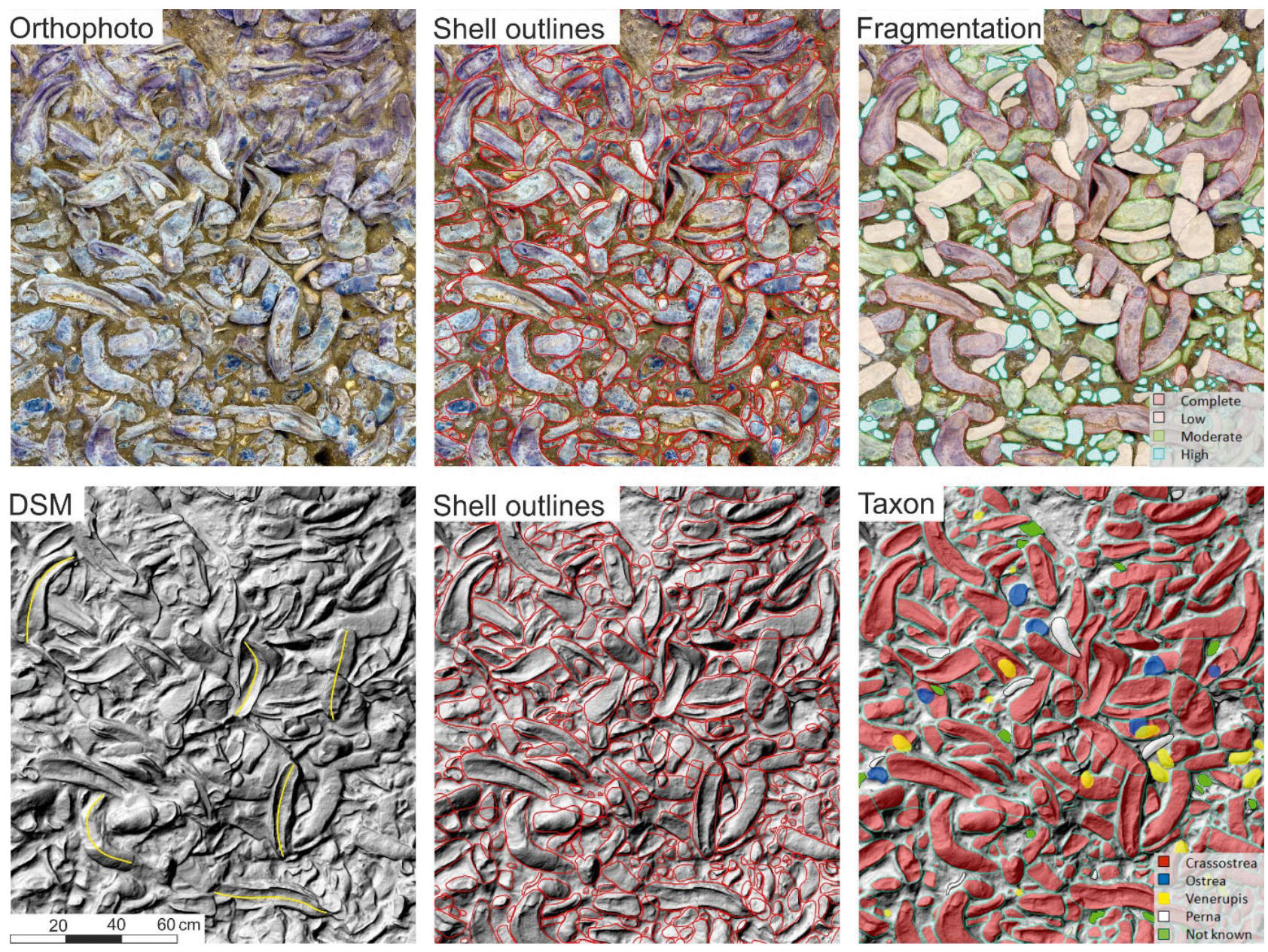

Fig. 4. Examples of population data acquisition on a fossilised oyster bed Crassostrea gryphoides: orthophoto and digital surface model (DSM) are used to define shell outlines manually. Together with the degree of fragmentation and species (taxon) identification, these data are georeferenced in an ArcGIS database. Yellow lines in the DSM are examples of centre lines (Harzhauser et al. 2016). Reproduced with permission of M. Harzhauser and Copernicus Publications

\section{FISH}

Otoliths are the traditional and most used AReS to estimate age in fishes. They can be preserved in large numbers in fossil assemblages, providing a tool for investigations of evolution of biodiversity when sampled in thousands (e.g. Schwarzhans 2003). Therefore, using otolith microstructure provides broad opportunities for studying the growth, age composition, and early life history of fossil fish (Woydack \& Morales-Nin 2001) and therefore, in theory, the natural mortality. One author's experience (V. Laptikovsky) in studying the diet of 22 different commercial and non-commercial fish and squid species of the Southwest Atlantic (Arkhipkin et al. 2012) demonstrated that otoliths and isolated vertebrae can remain intact within the guts before evacuation and therefore could potentially be deposited back into the natural environment. However, otoliths of fish brought by seabirds to nesting sites during the chick rearing period would end up somewhere onshore, invoking important bias for estimation of mortality in surfaceliving species. Also, by the end of digestion in seabirds, the otoliths usually have their outer layers corroded, making them often difficult even to identify to the species level and excluding any possibility of correct aging.

Otoliths represent a significant biogenic carbonate component and are common in bottom sediments (Lin et al. 2015, 2016 \& 2017a). Taxonomic composition and relative abundance of each taxon of otolith deathassemblages at various water depths conformed well to the distribution of the Mediterranean modern fish communities, though due to taphonomic particularities, otolith preservation (and potential readability) deteriorated in waters deeper than $500 \mathrm{~m}$ (Lin et al. 
$2017 b$ ). In this respect, it is important to note that among 13000 fossil Oligocene fish remnants collected in Poland, only 250 represented separate otoliths (presumably from predator stomachs), and $\sim 1500$ were isolated heads (Kotlarczyk et al. 2006). Contrast this with 7000 incomplete and 3314 complete skeletons possibly reflecting other sources of natural mortality (e.g. senility, periodically appearing anaerobic conditions). So, such materials exist and in theory could be used because the isolated heads and complete skeletons likely still contain otoliths. However, it is not always possible to destroy valuable fossils for an ecological study, a particular problem often occurring in paleozoology (Steele 2003).

However, there is at least one case where this approach could be applied to an important commercial species. Weddell seals prey intensively on large Antarctic toothfish under the ice sheet and characteristically remove the heads before consuming the rest. These heads (obviously still containing otoliths) accumulate around the seals' breathing holes and might be found there in dozens (Swithinbank et al. 1961, Kim et al. 2011). Because there is no fishery under the ice shelf and these waters are inaccessible to cetaceans, the seals could be the only important predator defining the species population dynamics in the area.

Other tools used to estimate age-related mortality of fish populations are vertebrae and scales. When taken from whole skeletons, even if the sample is relatively small, they can provide a useful insight about growth rates and general longevity to compare extinct and extant species (Newbrey \& Bozek 2003, Newbrey et al. 2007, 2008, 2015, Wilson et al. 2013). Analysis of fossilised scales of the Paleocene fish Joffrichthys triangulpterus revealed that fish age could be read from them (Fig. 5), with success being slightly more than half $(54.6 \%)$ though it required $6 \mathrm{yr}$ of biannual collection at the same paleontological site to obtain a necessary sample size (Newbrey \& Bozek 2003). Analysis of $A D$ of this laterally compressed, deep-bodied osteoglossid allowed estimation of the mortality rates for fish aged $3+\mathrm{yr}$ (Fig. 6) as $M=0.457$. This estimation seems to be reasonable for a mediumsized tropical fish of some 20 to $30 \mathrm{~cm}$ total length.

\section{MAMMALS}

\section{Collection data on age-at-death}

A common task in zooarchaeology is to estimate patterns of natural mortality caused by non-human

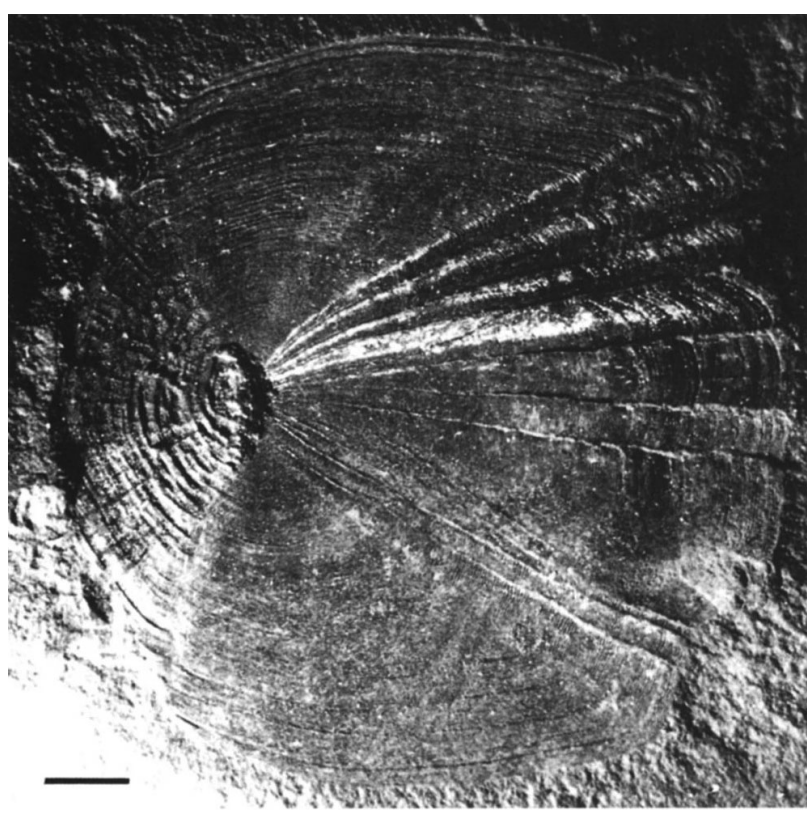

Fig. 5. A Joffrichthys triangulpterus fossil fish scale. The scale exhibits 6 annuli with each annulus representing a year of growth. Scale bar $=1 \mathrm{~mm}$ (Newbrey \& Bozek 2003).

Reproduced with permission of Taylor \& Francis Group

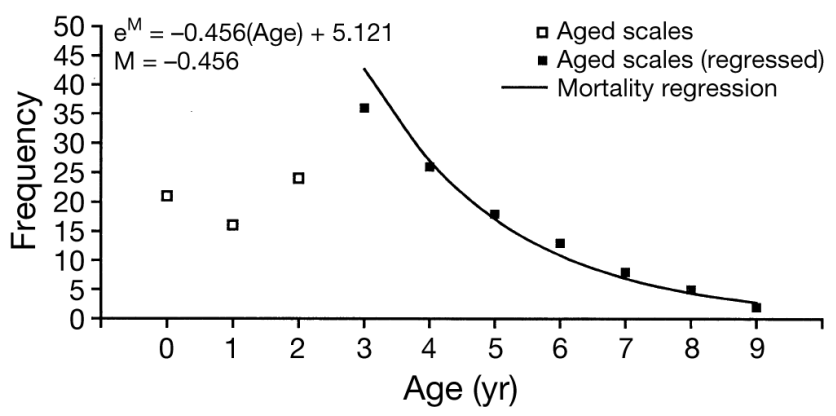

Fig. 6. Age frequency of Joffrichthys triangulpterus with age frequency superimposed over the data of age 3 and older fish (Newburg \& Bozek 2003). Reproduced with permission of Taylor \& Francis Group

carnivores usually harvesting vulnerable individuals vs. hunting mortality caused by humans that consistently take healthy adults, a unique feature among predators (Stiner 1990, Steele 2003). To some extent, the situation is like fishery science, where natural mortality of harvested marine mammals, fish and commercial invertebrates is estimated independently of fishing mortality. The sustainable fishing activity, at least in theory, is also aimed at avoiding the harvesting of juveniles, specimens of low commercial value (under-fed, senile, sick or damaged) and specimens of high reproductive value (avoidance of breeding aggregations, seasons and/or animals); so, in this respect, hunting is not very different from fishing. 
The type of the mortality profile on archaeological sites ('attritional', typical of natural mortality, vs. 'catastrophic', typical of hunting) allows to some extent a judgement of whether the species was mostly hunted or mostly scavenged by our distant hominid ancestors. When estimating human-caused mortality, the possibility that different-aged prey may be handled differently should be considered because it will affect resulting mortality profiles. With respect to natural mortality in the wild, juveniles are more likely to be fully consumed by predators or subsequent scavengers because of their small size and more cartilaginous bones, thus leaving no skulls for zooarchaeologists (Steele 2003). Generally, because archaeologists do not randomly sample target faunal remains, which means that sampling error is not randomly generated, it is recommended to limit analysis to descriptive statistics rather than involve inferential statistics (Wolverton et al. 2016).

Calculation of population-specific natural mortality rates is easy after sampling enough naturally dead animals, which is often not a problem for extant mammals (Fox et al. 2008) including marine mammals, though in the latter case there is often a question surrounding the cause of death: for example, what caused a whale to be stranded, or a seal to be washed onshore? This limitation obscures how representative the material is in respect to the animals that died at sea and drowned (see Evans \& Hindell 2004). A scientific sampling of teeth and/or earplugs in hunted marine mammals also provides materials to estimate total and hunting mortality (e.g. Chittleborough 1965, Aguilar \& Lockyer 1987, Barlow 1991, Bloch et al. 1993, Luque \& Ferguson 2010, Nielsen 2011).

There are 2 main approaches to estimate natural and hunting mortality based on dynamics of $A D$ in mammal populations: the growth ring method and the dental eruption and attrition method (for a review, see O'Connor 2000).

\section{Growth ring method}

The exact age of a wild mammal with obvious seasonal cycles of activity potentially could be estimated by counting the increments in cementum - an avascular bone-like tissue that serves to hold teeth in their sockets by providing a surface for attachment of the periodontal ligament (Fig. 7; Murphy et al. 2012). Growth rings form as the rate of cement accretion is not constant over the entire year and depends primarily on seasonal variations in diet; it is more intense

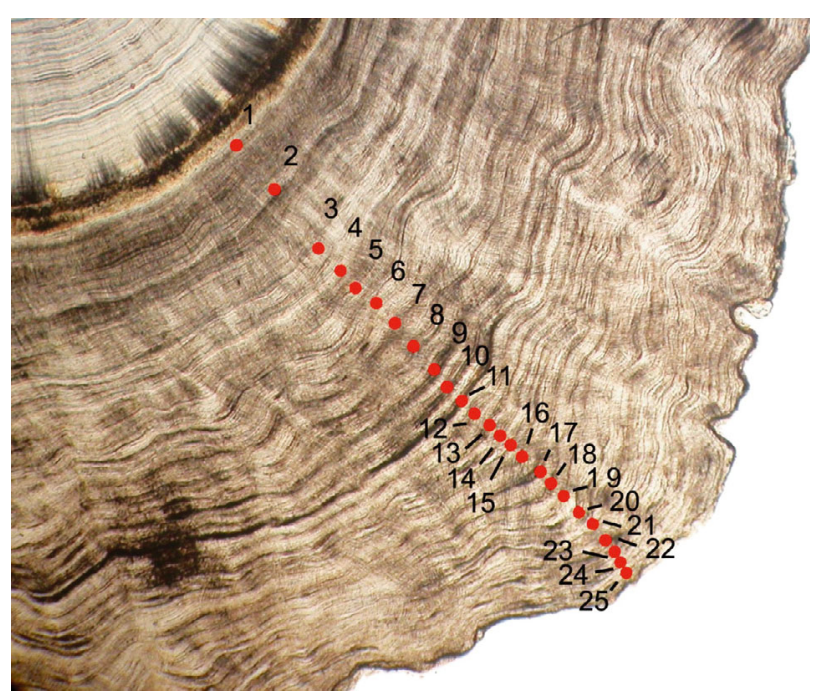

Fig. 7. Seal Monachus monachus growth layer groups observed in the unprocessed transverse section T1 under polarized light ( $\times 25$ magnification) obtained from a $25.5 \mathrm{yr}$ old unsexed individual (Murphy et al. 2012)

during the growing period when there is plenty of food (Lieberman 1993, 1994). Growth layers can be present also in dentine, sometimes being formed seasonally, twice per annum (Fig. 8; Brodie et al. 2013). In mammals with no obvious seasonality of life events, such as humans, there is still a correlation between the age of the individual and the thickness of the cementum, which has been used for many years to estimate the age of individuals in forensic studies

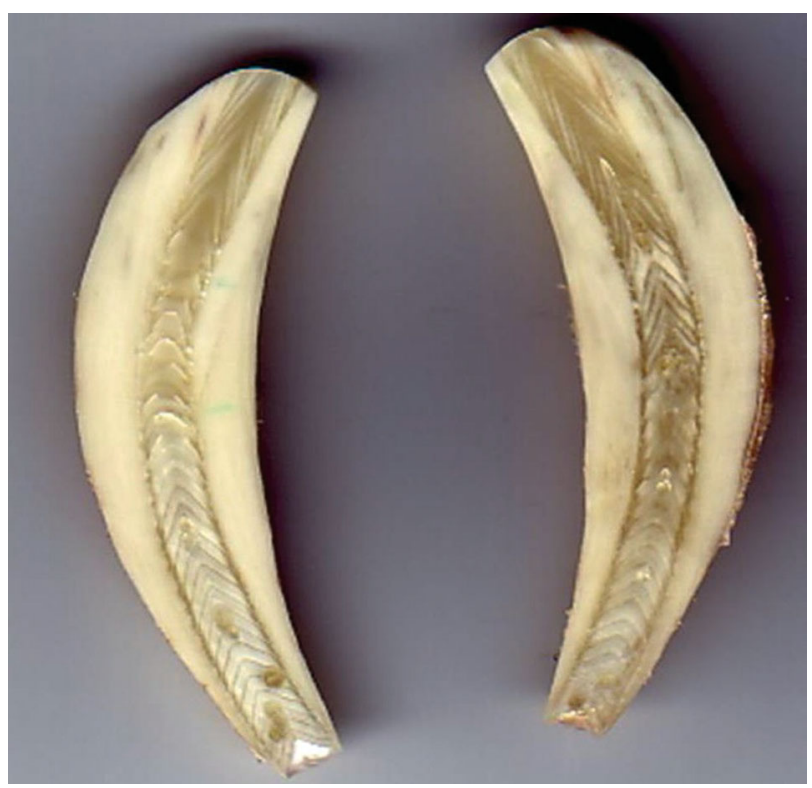

Fig. 8. Growth rings in dentine of an adult male beluga Delphinapterus leucas that are laid twice per year (photo: Dr. P. Brodie) 
(O'Connor 2000). Because growth rings are deposited seasonally in the wild, there is also a possibility to estimate in what season the animal died-an approach applied to such animals as goats, gazelles, mammoths, cave bears and lions (Lieberman \& Meadow 1992, Lieberman 1993, Fisher et al. 2003, Fišáková 2014, El Adli et al. 2015). In marine mammals, the annual growth rings can additionally be counted on earplugs, which also carry indispensable information on other life history events such as attaining sexual maturity, exposure to contaminants, reconstruction of life-time profiles of hormonal activities (e.g. Ruud \& Jonsgård 1950, Ottestad 1950, Trumble et al. 2013).

The annual regularity of dentine increments still needs validation, though there is a consensus that this method can be applied to some species, taking into account that $A D$ might be underestimated above a particular age (Adams \& Watkins 1967, Keay 1996, O'Connor 2000). Also, the estimated age might depend on what tooth has been chosen (Roberts 1978, Lanteri et al. 2013). Annual formation of growth rings in cetacean earplugs is confirmed (e.g. Roe 1968, Gabriele et al. 2010) though reading them might also present difficulties in some species or age groups (e.g. Sukhovskaya et al. 1985, Aguilar \& Lockyer 1987).

However, the cementum annuli method to calculate natural morality is of a limited use in zooarchaeology and palaeontology because (1) it is time-consuming and requires expertise, (2) it requires large samples to reconstruct accurate mortality profiles, and (3) most archaeologists are reluctant to destroy irreplaceable fossils (Steele 2003). The same issues also apply to extinct marine mammals whose teeth could be aged (e.g. Lambert et al. 2008, Murakami et al. 2015), but the collected data were never sufficient to draw any conclusions about natural mortality rates.

Sample sizes available even for extant marine mammals could be insufficient to calculate mortality and its confidence intervals. Because of this, authors often apply inferential statistics or just a description (Murphy et al. 2012). Analysis of data on $A D$ and cause of death of a threatened Mediterranean monk seal Monachus mo- nachus revealed that sub-adults are particularly prone to accidental fishery-related death, as they may be less cautious and less experienced. Upon attaining the age of $3 \mathrm{yr}$, the anthropogenic mortality persists mostly as deliberate killing, which occurs throughout the life cycle; after $10 \mathrm{yr}$, non-human induced death (natural mortality) becomes important (Fig. 9).

\section{Dental eruption and attrition method}

This method is the most used in mammal studies (Steele 2003) though it has an important drawback: it is generally applicable to living species only (or to their closest relatives) because it is not known at what age teeth erupted in extinct animals. To use data on tooth eruption, there should be a reference range of observations on animals of all ages kept in captivity since birthdate. Another issue is that genetically driven physiological processes as well as environmental circumstances may affect eruption in one or all individuals of the population (O'Connor 2000). Rates of teeth wearing may vary between individuals

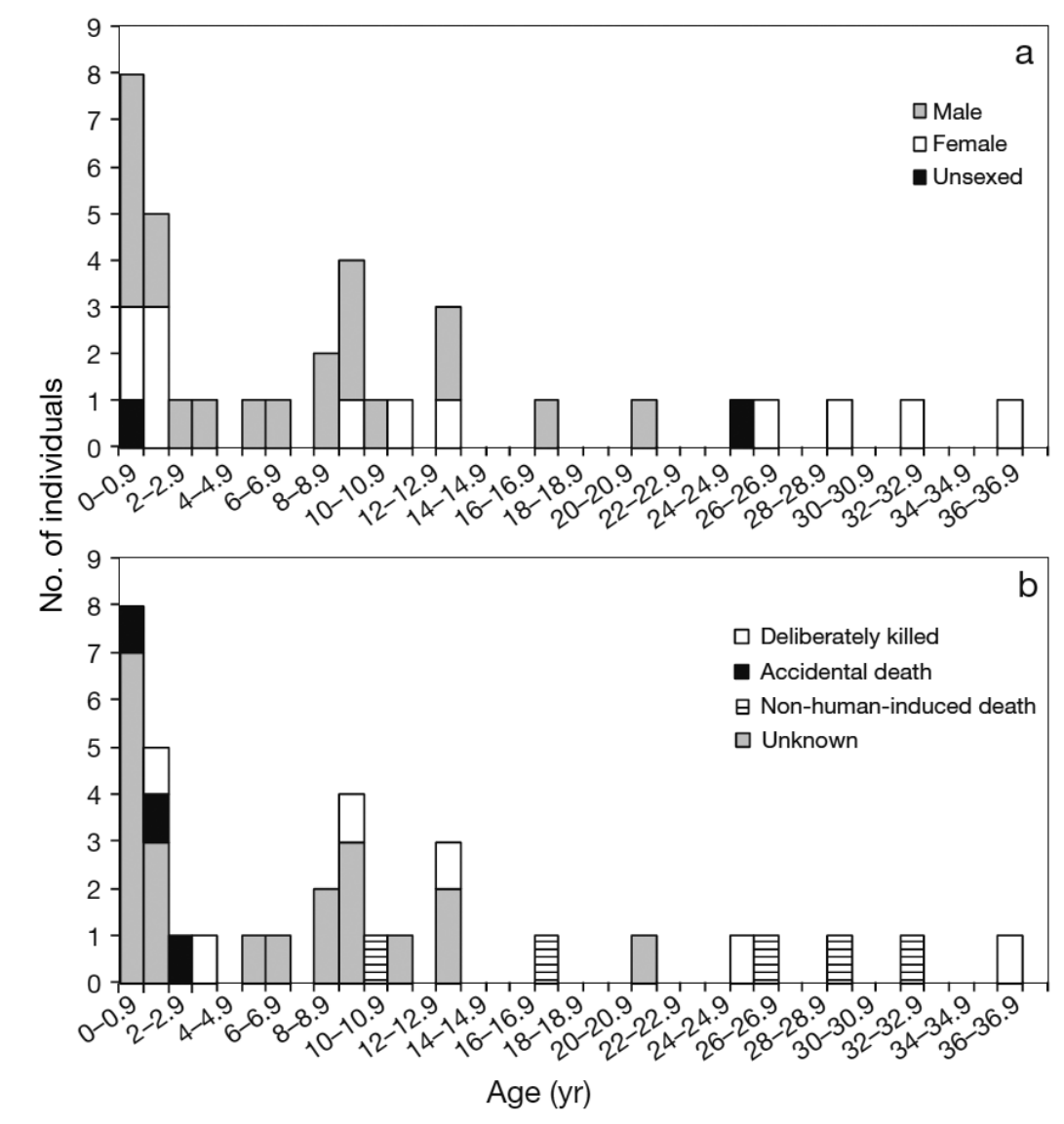

Fig. 9. Age frequency distribution of the seal Monachus monachus by sex and death categories (Murphy et al. 2012) 
and populations, possibly because of differences in diet or degree of enamel mineralization (for a review, see Steele 2003). After allocation of every dead animal to an age range, scientists create the mortality profile as histograms or line graphs that show the proportion (either frequency or percentage) of individuals that died in each age class. Relative age is often expressed in a percentage of life span assuming constant tooth attrition rates.

\section{Histological and chemical set of methods}

The third group of methods relies on the examination of histology and chemistry of bones and other structures for comparison to a known-age series. The common technique of those used for marine mammals is called aspartic acid racemization (AAR) which measures the ratio of the 2 enantiomers of the amino acid, aspartic acid (D and L) in the eye lens as applied to bowhead, Minke and fin whales and harbour porpoises (e.g. George et al. 1999, Olsen \& Sunde 2002, Nielsen 2011, Rosa et al. 2013). This implies that death was very recent, with the date known to researchers. For application of these techniques for aging time-averaged archaeological samples, see below.

\section{Methods applicable to humans only}

Analysis of methods applicable for description of human mortality rates is generally outside of the scope of this article, so we restrict ourselves to some general notions. In studies of pre-historical population dynamics, the human age might be estimated the same way as in other mammals. However, demographical records through the last 2 to 3 thousand years of human history provide abundant data on individual $A D$ as recorded on such reliable AReS as tombstones coming from ancient civilisations, for example the 43000 inscriptions that have survived from the Western Roman Empire alone (Holleran \& Pudsey 2011, Woods 2007). In many cases (like Christian funerary commemorations of 4 to $5^{\text {th }}$ centuries), an epitaph contains the exact date of death, which permits the description of seasonal dynamics of mortality, which in the case of the city of Rome, peaked in late summer to early autumn (Scheidel 2015). However, epitaphs are selective in recording age of death, as gender and class are shown to determine the likelihood of epigraphic commemoration (Hopkins 1987, Scheidel 2001), so epitaphs are not entirely dissimilar to AReS of animal kingdom, being subjected to similar sources of bias. Data on $A D$ can be also found in written sources such as records of births and deaths in recent centuries. Some of these records can be really outstanding, such as the genealogy of the Qing (1644-1911) imperial lineage containing data on births and deaths of 33000 lineage members born in Beijing between 1700 and 1840 (Lee et al. 1994).

\section{TIME-AVERAGING AND THANATOCOENOSIS DATING}

One of the problems in interpreting data from thanatocoenoses is the time-averaging of samples through the build-up of fossilised deposits when multiple generations of organisms are mixed into a single stratigraphic horizon. Such a time-averaged sample might increase variability above that found in living populations with just a few generations available for sampling. Also, it might alter correlations between morphological variables and obscure allometric relationships in evolving populations (Bush et al. 2002). However, natural mortality is a process and could be estimated only over (and in reference to) a period of time. It is different from an instantaneous morphological feature (like a shell length) that can be directly measured as a part of sample and to be related to a particular static situation. Therefore, the time-averaging effect should not prevent comparison of species-specific mortalities between different epochs that could be problematic for morphological studies. For example, analysis of $A D$ read in vertebrae of extinct pikes (Newbrey et al. 2008) allowed a comparative analysis of population growth rates from the Campanian (Cretaceous) to the present day. At the studied scale of some $80 \mathrm{MY}$ duration, the time-averaging of samples collected in sediments of particular short-term geological formations (such as the Hell Creek formation 66.8 to 66 MYA or the Oldman formation 77.5 to 76.5 MYA) does not bring any important bias. It demonstrates an ample possibility of studying large collections of isolated vertebrae and fossilised scales of extinct fish, that might permit estimation not only of growth rates and longevities (Newbrey et al. 2008), but also of natural mortality.

Analysis of molluscan shells from recent, non-fossilised death assemblages raises 2 important issues. First, when collecting shells buried in sediment (e.g. from a depth of 5 to $20 \mathrm{~cm}$ using a grab), some could be a thousand or even tens of thousands of years old, thus making the 'assemblage time window' very wide. Second, the age of shells within this 'window' 
would be skewed to the left, with recently dead molluscs predominating over those that died thousands of years ago (for a review, see Kidwell 2013). These problems should be considered and addressed when planning a study and interpreting results.

Another issue is an increase in species richness (often $\sim 25 \%$ higher than living communities) found within the assemblages (Bush et al. 2002, Kidwell 2002, 2013, Kidwell \& Rothfus 2010). This is possibly a result of short-term (i.e. seasonal in fish or decadal in molluscs) changes in species ranges that potentially might combine time-averaging with some kind of spatial-averaging.

The general age of the deposits is often determined using radiocarbon dating (Koppel et al. 2016, Thomas 2015); however, advances in an alternative technique, amino acid racemization (AAR), mentioned earlier in regard to corals, may have enhanced the ability of researchers to disentangle the time-averaging within shell middens (Koppel et al. 2016, 2017). There are good and bad aspects to both techniques with regards to mollusc shell material.

Radiocarbon dating relies on the predictable decay of ${ }^{14} \mathrm{C}$, a radioactive isotope of carbon, over time, which can be measured using accelerator mass spectrometry, resulting in a date range within which the sample lived. Radiocarbon dating of marine shells is often subject to the marine reservoir effect. This occurs when the water used as a source of carbon (and importantly ${ }^{14} \mathrm{C}$ ) during shell formation comes from the deep ocean, representing water which is much older than the upper layers of seawater that are in equilibrium with the atmosphere (Bowman 1995, Jull et al. 2013). This causes the radiocarbon dates to be potentially hundreds of years older than the actual date of formation. There are now well known calibration methods to account for the marine reservoir effect (Ascough et al. 2005). However, these calibrations may also differ significantly when estuarine samples are analysed because terrestrial sources of carbonate (from rock and soil) can alter the ${ }^{14} \mathrm{C}$ signal (Reimer 2014). When radiocarbon dating archaeological samples, there is also the possibility that diagenesis has altered the ${ }^{14} \mathrm{C}$ signal within the shell. This occurs when metastable aragonite, present in many marine mollusc shells, transitions to the more stable polymorph of calcite over time. This process can draw carbon from the surrounding environment into the outer layers of the shell, resulting in a radiocarbon age different (younger or older) than that of the original shell (Thomas 2015). Where possible, it is advised to avoid diagenetic shell material. This was achieved by Mannino \& Thomas (2001) by removing the outer layers of the shell of Monodonta lineata altogether and only sampling the inner shell layers.

AAR measures the proportion of an amino acid that has transitioned from the L-form, which is used by living organisms, to the stereoisomer D-form following death, this process is also known as racemization (Thomas 2015). Glycine does not have a stereoisomer and is therefore unsuitable; it should also be noted that different amino acids have different rates of racemization (Grimley \& Oches 2015, Thomas 2015). This change happens naturally over time at a predictable rate, and so the ratio of $\mathrm{L}$ isomers to $\mathrm{D}$ isomers within a sample can be used to estimate the age. AAR presents a different set of challenges to those observed for radiocarbon dating. Unlike the decay of ${ }^{14} \mathrm{C}$, the rate of racemization can vary with a variety of environmental conditions such as $\mathrm{pH}$ and temperature (Canoira et al. 2003). This means that good knowledge of the surrounding environmental history is often required. For mollusc shells, improvements in the analytical methods and recent work investigating intra-crystalline amino acids, which possibly act as closed systems with minimal external influence (Demarchi et al. 2011, 2013a,b), has improved the future potential of this technique. Although improvements are still required because disparities between analytical results from different labs are still common (Powell et al. 2013, Wehmiller 2013, Thomas 2015), recent work has also highlighted the possibility of calibrating AAR analyses with radiocarbon dating to ensure confidence in the resulting data (Kosnik et al. 2013, Simonson et al. 2013).

Coral samples can be dated using both the radiocarbon and AAR methods (Goffer 2007). In Hawaiian waters, Roark et al. (2006) applied radiocarbon $\left({ }^{14} \mathrm{C}\right.$ and 'bomb ${ }^{14} \mathrm{C}$ ') dating to determine ages and growth rates of pink coral Corallium secundum, gold coral Gerardia sp. and 2 black corals (Leiopathes glaberrima and Antipathes dichotoma). This research followed differences in coral ageing using radiocarbon and $\mathrm{AAR}_{\text {; }}$ on an Atlantic Gerardia specimen, Druffel et al. (1995) recorded a basal age of $1800 \pm 300 \mathrm{yr}$ when using ${ }^{14} \mathrm{C}$. However, AAR dating carried out on the same specimen revealed an age of no more than 250 yr (Goodfriend 1997). Roark et al. (2009) considers that high heat experiments were responsible for determining the amino acid date; as the coral grew in low temperatures, the heat experiments may not linearly extrapolate to the lower temperatures associated with the coral. Furthermore, it is considered that AAR is also influenced by the amino acid composition of the protein, amino acid concentration in the water, $\mathrm{pH}$ and ionic strength of the environment, 
which could be unknown factors when assessing coral age. Until uncertainty surrounding these is decreased, Roark et al. (2009) consider ${ }^{14} \mathrm{C}$ radiocarbon dating to be the more accurate tool for coral ageing. In contrast, Robbins et al. (2001) think the 2 methods go hand-in-hand; where amino acid uncertainties are apparent, the methods can be calibrated using ${ }^{14} \mathrm{C}$ dating to generate a 'constant' used to assess an age based on the calibrated sample.

\section{DISCUSSION AND CONCLUSIONS}

Our study reviews methods applied in marine biology and fisheries management, palaeobiology, archaeology and demography. These very different disciplines use the same approach: collection of information from AReS about $A D$ and summarising it into mortality profiles. These profiles allow the reconstruction of mortality rates through ontogeny, often distinguishing between natural and anthropogenic mortalities. The AReS might contain more information than just age, but also the season of death (mammals and bivalve molluscs in which it might be judged from the distance between the last growth ring and AReS edge) or even the date of death (humans) that provide a possibility of even a deeper insight into the species' ecology. Most of these body elements register the age due to the seasonal changes of metabolism leading to formation of annual growth rings. However, when the size of a dead animal is known and the species is characterised by indeterminate growth (e.g. molluscs; Sebens 1987, Ridgway et al. 2011), the age structure of thanatocoenoses could be estimated via age-length keys available from live animals (if dead and live animals are contemporary), thus providing indirect age structure assessment for calculation of mortality.

A particular case of mortality is represented by corals in which mortality can be partial. After part of a colony dies, and the rest survives, making inferential statistics becomes next to impossible. In theory, any of the described methods could be viable in ascertaining coral $A D$. However, it is evident that no one technique will be applicable to all coral specimens. Indeed, radiocarbon dating may be the most accurate, but is also likely to be the costliest technique to carry out. Baseline information on targeted species' life-history is therefore invaluable to determine which technique is needed for accurate estimates. Growth-ring analysis may be sufficient for shorter-living and continuously growing species, whereas radiocarbon dating might be more appropri- ate for long-living species which have an excessive number of growth rings, particularly, ones in which the rings may be very difficult to identify.

In most cases except coral reef colonies, the approach follows the principle 'one animal-one sample', like sectioning a particular half of a bivalve shell or one particular type or tooth (e.g. incisor). Therefore, often authors, mostly palaeontologists, do not need the entire organism to be collected, but sample instead the available isolated parts: shells (or even parts of shells as in the rostra of belemnites), animal teeth, fish scales, otoliths and vertebrae bearing information on age at death, and assert that one item represents one animal. To some extent, this assumption might be reasonable as different specimens will have similar (vertebrae, teeth and scales) or the same (otoliths or shell valves) numbers of AReS. In this case, a researcher often faces the problem of species identification, which can be challenging even in archaeological mammals (Steele 2003) let alone fossilised paleontological materials.

A reconstruction of the mortality profile and its interpretation requires application of inferential statistics, assuming that the collected sample is unbiased so population parameters might be inferred from its statistical properties. Because of this, the collection of data from thanatocoenoses requires a range of issues to be addressed before the study is carried out. Otherwise only descriptive statistics are possible.

(a) Within the studied range of ages, the probability of the individual AReS to be fossilised and thus being available for sampling should be the same for any age class. Mortality factors (like predators and environmental events) should not alter or destroy AReS after death;

(b) AReS of the studied range of ages should be randomly distributed within the sampled area. If mortality of animals at the different ontogenetic stages (e.g. immature vs. adult) occurs mostly in the different areas, it might provide an important source of bias;

(c) The AReS should be abundant enough not to restrict the available sample size, which might be assigned based on goals of the study and randomness of sample collection ensured;

(d) Ageing methods applied to archaeological and palaeontological data are verified and consistent; age reading done by the same persons using the same methodology; and

(e) The time-averaging factor should be negligible for the studied time scale and accounted for when interpreting the results.

In respect to practical application, all approaches to estimate mortality (natural and anthropogenic) that 
were applied in the past and could be applied in future studies might be summarised as follows:

(1) No anthropogenic mortality exists or it is negligible (palaeontology, non-commercially exploited taxa of invertebrates, zooarchaeology and human demography):

(1.1) Collection of data on individual $A D$ assuming as much randomness as possible (molluscan shell beds, coral reefs, growth ring method in mammals, cemeteries), and then reconstructing the mortality profile and estimating natural mortality rates between adjacent age groups using inferential statistics (e.g. Fox et al. 2008, Harzhauser et al. 2016).

(1.2) Collection of data on individual $A D$ in documented multi-annual death events like sperm whale strandings (Evans \& Hindell 2004), harbour porpoises bycaught and stranded (Lockyer \& Kinze 2003) and monk seals washed onshore (Murphy et al. 2012). Because randomness of sampling cannot be guaranteed, descriptive statistics are applied rather than inferential statistics.

(1.3) Collection of data on some feature indicating the most probable $A D$ in the natural habitat (e.g. degree of teeth attrition in mammals, shell size in non-commercial gastropods) and then reconstructing the mortality profile and respective estimation of mortality rates. Inferential statistics is possible based on some additional assumptions.

(2) Both natural and anthropogenic mortality exist (extant commercial or commercial-in-the past species of invertebrates, fishes and mammals including zooarchaeology):

(2.1) Collection of data on age structure of recently dead shells and live shells from the same habitat in molluscan species where such direct aging is possible (scallops, oysters, etc.), then reconstructing natural mortality and survival, respectively. Collection of data on age structure of landed molluscs combined with landing weight will provide harvest at age. This in combination with known difference between natural mortality and survival will provide an estimation of fishing mortality, stock size and harvest rate. This method could be applicable only to molluscs where dead shells do not accumulate over time on fishing grounds and that are not processed at sea so dead shells are disposed somewhere else (Laptikhovsky et al. 2016).

(2.2) Collection of data on some feature indicating the most probable $A D$ from the natural habitat and from human middens. The method is applied mostly in zooarchaeology (e.g. Steele 2003), and because the proportion between animal death from natural causes and hunting by humans is unknown, descriptive statistics should be applied.
All these methods might generally be applied to relatively stable populations without sudden fluctuations in mortality during the studied size/age range. In species with highly changeable survival rates, such a methodology will have ecological sense only if catastrophic events are a regular part of population history, repeating over several generations such as strong El Niño events in the contemporary East Pacific. However, it would be senseless to calculate the mean mortality of a population that passed through a single large catastrophe, as for some ammonites that survived the end-Cretaceous extinction into early Paleocene (Landman et al. 2014); the calculated value would be misleading. We do not consider time-averaging to be detrimental to methods reviewed here even if populations are not entirely stable. However, other population parameters like growth rates or size-at-maturity that might be estimated from the same materials could be heavily impacted. A typical example of such a potential problem are the most important commercial squids Loligo spp., Todarodes spp. and Illex spp. that normally live for just 1 yr (so have the same annual mortality rates) but for which growth and maturation rates vary significantly between years due temperature variations. For such species, time-averaging does not pose a problem when mortality is estimated but should be taken into consideration when other life cycle parameters are of interest. However, to take into account the scale at which the time-averaging occurs, the researcher in most cases needs the exact age range when the studied thanatocoenosis was deposited. Therefore, all pros and cons of radiocarbon dating versus AAR discussed above should be carefully considered.

Numerous possible sources of bias should be considered when reconstructing mortality profiles and calculating natural mortality and/or natural + anthropogenic mortalities. Not all aforementioned approaches and techniques are transferrable from one field to another because they were elaborated for organisms with different morphologies and ecologies, but cross-fertilisation of ideas might provide a new insight into studies related to population dynamics.

Analysis of age structure of thanatocoenoses could help with solving large problems like studying population response to climate change in the geological and/or archaeological past and evolution of life cycle parameters in changing environments (e.g. Newbrey \& Ashworth 2004, Newbrey et al. 2008, Rick et al. 2016). Achievement of these tasks might require analysis of numerous collections scattered in the different museums and co-ordination of efforts of 
several scientific bodies. Such an approach could be simplified by development of exhaustive archaeological/paleontological databases containing information on specimens available for comparative palaeo-ecological studies. However, data collected with different tasks in mind could be difficult to compare. As was exemplified with materials on oysters Crassostrea virginica, differences in spatial and temporal resolution and extent of prehistoric, historic and modern ecological data could be an obstacle for their integration. It is because these data generally are not collected to study particular ecological topics like changes in oyster size, growth and colony accretion rates (Rick \& Lockwood 2013). However, at the larger scale when the problem of time-averaging is of less importance, it is possible to, for example, track changes in oyster size from the Pleistocene to modern times (Rick et al. 2016). Often, time-averaging is a necessary procedure to obtain evolutionary sensible estimations because amalgamating data from a geological formation of hundreds of thousands of years duration would help avoid such sources of bias as seasonal migrations and inter-annual variability of climate. Application of every methodology and interpretation of results always should be considered with actual circumstances of sample collection because those strongly impact the accuracy of estimations.

Acknowledgements. The authors sincerely thank Drs. Mary Ann Muller (Taylor \& Francis Group), Charlotte Winsnes (North Atlantic Marine Mammal Commission), Paul Brodie (Balaena Dynamics, Halifax), Mathias Harzhauser (Natural History Museum Vienna), Hubert Wierzbowski (Polish Geological Institute), George Rose (Elsevier Publishing Group), Kathleen Huber (PALAIOS Managing Editor) and Anna Wenzel (Copernicus GMBH) who granted permissions to use their images to illustrate this review; Prof. Chris Richardson (Bangor University) for the specimen of Chesapecten sp.; and Dr. David Righton (Cefas), Dr. M. G. Newbrey (Royal Tyrrell Museum of Palaeontology) and 3 anonymous reviewers for valuable comments.

\section{LITERATURE CITED}

Adams L, Watkins SG (1967) Annuli in tooth cementum indicate age in California ground squirrels. J Wildl Manag 31:836-839

Aguilar A, Lockyer CH (1987) Growth, physical maturity, and mortality of fin whales (Balaenoptera physalus) inhabiting the temperate waters of the northeast Atlantic. Can J Zool 65:253-264

* Aller JY (1995) Molluscan death assemblages on the Amazon Shelf: implication for physical and biological controls on benthic populations. Palaeogeogr Palaeoclimatol Palaeoecol 118:181-212

Andresen H, Strasser M, van der Meer J (2014) Estimation of density-dependent mortality of juvenile bivalves in the
Wadden Sea. PLOS ONE 9:e102491

*Andrus CFT (2011) Shell midden sclerochronology. Quat Sci Rev 30:2892-2905

Arkhipkin A, Brickle P, Laptikhovsky V, Winter A (2012) Dining hall at sea: feeding migrations of nektonic predators to the eastern Patagonian Shelf. J Fish Biol 81: 882-902

Ascough P, Cook GT, Dugmore AJ (2005) Methodological approaches to determining the marine radiocarbon reservoir effect. Prog Phys Geogr 29:532-547

Babcock RC (1991) Comparative demography of three species of scleractinian corals using age- and size-dependent classifications. Ecol Monogr 61:225-244

Bak RPM, Meesters EH (1998) Coral population structure: the hidden information of colony size-frequency distributions. Mar Ecol Prog Ser 162:301-306

* Barbeau MA, Scheibling RE, Hatcher BG, Taylor LH, Hennigar AW (1994) Survival analysis of tethered juvenile sea scallops (Placopecten magellanicus) in field experiments: effects of predators, scallop size and density, site and season. Mar Ecol Prog Ser 115:243-256

Barlow J (1991) Modelling age-specific mortality for marine mammal populations. Mar Mamm Sci 7:50-65

* Best PB, Kishino H (1998) Estimating natural mortality rate in reproductively active female southern right whales, Eubalaena australis. Mar Mamm Sci 14:738-749

Bloch D, Lockyer C, Zachariassen M (1993) Age and growth parameters of the long-finned pilot whale off the Faroe Islands. Rep Int Whaling Comm 14:163-208

Boucot AJ (1953) Life and death assemblages among fossils. Am J Sci 251:25-40

Bowman S (1995) Radiocarbon dating. British Museum Press, London

Brocken F, Kenchington E (1999) A comparison of scallop (Placopecten magellanicus) population and community characteristics between fished and unfished areas in Lunenburg county, NS, Canada. Can Tech Rep Fish Aquat Sci 2258

Brodie P, Ramirez K, Haulena M (2013) Growth and maturity of belugas (Delphinapterus leucas) in Cumberland Sound, Canada, and in captivity: evidence for two growth layer groups (GLGs) per year in teeth. J Cetacean Res Manag 13:1-18

* Burchell M, Cannon A, Hallmann N, Schwarcz HP, Schöne BR (2013) Refining estimates for the season of shellfish collection on the Pacific Northeast Coast: applying high resolution stable oxygen isotope analysis and sclerochronology. Archaeometry 55:258-276

Bush AM, Powell MG, Arnold WS, Bert TM, Daley GW (2002) Time-averaging, evolution and morphologic variation. Paleobiology 28:9-25

Caddy JF (1989) A perspective on population dynamics and assessment of scallop fisheries, with special reference to the sea scallop, Placopecten magellanicus Gmelin. In: Caddy JF (ed) Marine invertebrate fisheries: their assessment and management. Wiley \& Sons, New York, NY, p 559-589

*adée GC (2002) Floating articulated bivalves, Texel, North Sea. Palaeogeogr Palaeoclimatol Palaeoecol 183:355-359

* Canoira L, García-Martínez MJ, Llamas JF, Ortíz JE, Torres TD (2003) Kinetics of amino acid racemization (epimerization) in the dentine of fossil and modern bear teeth. Int J Chem Kinet 35:576-591

K Caroselli E, Zaccanti F, Mattiolo G, Falini G, Levy O, Dubinsky Z, Goffredo S (2012) Growth and demography of the 
solitary scleractinian coral Leptopsammia pruvoti along a sea surface temperature gradient in the Mediterranean Sea. PLOS ONE 7:e37848

Chadwick-Furman NE, Goffredo S, Loya H (2000) Growth and population dynamic model of the reef coral Fungia granulosa Klunzinger, 1879 at Eilat, northern Red Sea. J Exp Mar Biol Ecol 249:199-218

* Chinzei K (2013) Adaptation of oysters to life on soft substrates. Hist Biol 25:223-231

Chittleborough RG (1965) Dynamics of two populations of the humpback whale, Megaptera novaeangliae (Borowski). Aust J Mar Freshw Res 16:33-128

Christmas JF, McGinty MR, Randle DA, Smith GF, Jordan SJ (1981) Oyster shell disarticulation is three Chesapeake Bay tributaries. J Shellfish Res 16:115-123

Ciocco NF (1996) 'In situ' natural mortality of the Tehuelche scallop, Aequipecten tehuelchus (d'Orb, 1846), from San José Gulf (Argentina). Sci Mar 60:461-468

Cormack RM (1964) Estimates of survival from sighting of marked animals. Biometrika 51:429-438

Demarchi B, Williams MG, Milner N, Russell N, Bailey G, Penkman K (2011) Amino acid racemization dating of marine shells: a mound of possibilities. J Archaeol Sci 239:114-124

Demarchi B, Rogers K, Fa DA, Finlayson CJ, Milner N, Penkman KEH (2013a) Intra-crystalline protein diagenesis (IcPD) in Patella vulgata, part I: isolation and testing of the closed system. Quat Geochron 16:144-157

Demarchi B, Collins MJ, Tomiak PJ, Davies BJ, Penkman $\mathrm{KEH}$ (2013b) Intra-crystalline protein diagenesis (IcPD) in Patella vulgata, part II: breakdown and temperature sensitivity. Quat Geochron 16:158-172

*Dickie LM (1955) Fluctuations in abundance of the giant scallop, Placopecten magellanicus (Gmelin), in the Digby area of the Bay of Fundy. J Fish Res Board Can 12:797-857

Druffel ERM, Griffin S, Witter A, Nelson E, Southon J, Kashgarian M, Vogel J (1995) Gerardia: bristlecone pine of the deep-sea? Geochim Cosmochim Acta 59:5031-5036

El Adli JJ, Cherney MD, Fisher DC, Harris JM, Farrell AB, Cox SM (2015) Last years of life and season of death of a Columbian mammoth from Rancho La Brea. Nat Hist Mus Los Angel Cty Sci Ser 42

Evans K, Hindell MA (2004) The age structure and growth of female sperm whales (Physeter macrocephalus) in southern Australian waters. J Zool (Lond) 263:237-250

Fišáková MN (2014) Seasonality of use of za Hájovnou cave by bears and lions. Acta Mus Nat Prague Ser B Hist Nat 70:103-106

Fisher DC, Fox DL, Agenbroad LD (2003) Tusk growth rate and season of death of Mammuthus columbi from Hot Springs, South Dakota, USA. In: Reumer JWF, De Vos $\mathrm{J}$, Mol D (eds) Advances in mammoth research: Proc 2nd Int Mammoth Conf, Rotterdam, 16-20 May 1999. Deinsea 9:117-133

Fox S, Luly J, Mitchell K, Maclean J, Westcott DA (2008) Demographic indications of decline in the spectacled flying fox (Pteropus conspicillatus) on the Atherton Tablelands of northern Queensland. Wildl Res 35:417-424

Gabriele CM, Lockyer C, Straley JM, Jurasz CM, Kato H (2010) Sighting history of a naturally marked humpback whale (Megaptera novaeangliae) suggests ear plug growth layer groups are deposited annually. Mar Mamm Sci 26:443-450

George GC, Bada J, Zeh J, Scott L, Brown SE and others (1999) Age and growth estimates of bowhead whales
(Balaena mysticetus) via aspartic acid racemization. Can J Zool 77:571-580

* Gislason H, Pope JG, Rice JC, Daan N (2008) Coexistence in North Sea fish communities: implications for growth and natural mortality. ICES J Mar Sci 65:514-530

Glassom D, Zakai D, Chadwick-Furman N (2004) Coral recruitment: a spatio-temporal analysis along the coastline of Eilat, northern Red Sea. Mar Biol 144:641-651

Goffer Z (2007) Archaeological chemistry, 2nd edn. WileyInterscience, Hoboken, NJ

Goffredo S, Lasker HR (2006) Modular growth of a gorgonian coral can generate predictable patterns of colony growth. J Exp Mar Biol Ecol 336:221-229

*Goffredo S, Lasker HR (2008) An adaptive management approach to an octocoral fishery based on the Beverton Holt model. Coral Reefs 27:751-761

* Goodbody-Gringley G, Marchini C, Chequer AD, Goffredo S (2015) Population structure of Montastraea cavernosa on shallow versus mesophotic reefs in Bermuda. PLOS ONE 10:e0142427

Goodfriend GA (1997) Aspartic acid racemization and amino acid composition of the organic endoskeleton of the deep-water colonial anemone Gerardia: Determination of longevity from kinetic experiments. Geochim Cosmochim Acta 61:1931-1939

Gosling E (2004) An introduction to bivalves. Bivalve molluscs: biology, ecology and culture. Fishing News Books, Blackwell, Oxford

Grimley DA, Oches EA (2015) Amino acid geochronology of gastropod-bearing Pleistocene untis in Illinois, central USA. Quat Geochronol 25:10-25

* Gunderson DR, Dygert PH (1988) Reproductive effort as a predictor of natural mortality rate. J Cons Int Explor Mer 44:200-209

Hallam A (1967) The interpretation of size-frequency distributions in mollusc death assemblages. Palaeontology 10: 25-42

*Hart MB, Clarke MR, Jonghe AD, Price GD, Page KN, Smart CW (2015) Statoliths from the Jurassic succession of south-west England, United Kingdom. Swiss J Palaeontol 134:199-205

* Harzhauser M, Piller WE, Müllegger S, Grunert P, Micheels A (2011) Changing seasonality patterns in Central Europe from Miocene Climate Optimum to Miocene Climate Transition deduced from the Crassostrea isotope archive. Global Planet Change 76:77-84

*Harzhauser M, Djuricic A, Mandic O, Neubauer TA, Zuschin M, Pfeifer N (2016) Age structure, carbonate production and shell loss rate in an Early Miocene reef of the giant oyster Crassostrea gryphoides. Biogeosciences 13:1223-1235

Hewitt DA, Hoenig JM (2005) Comparison of two approaches for estimating natural mortality based on longevity. Fish Bull 103:433-437

K Hewitt DA, Lambert DM, Hoenig JM, Lipcius RN and others (2007) Direct and indirect estimates of natural mortality for Chesapeake Bay blue crab. Trans Am Fish Soc 136: 1030-1040

Holleran C, Pudsey A (2011) Demography and the GraecoRoman world. Cambridge University Press, Cambridge

Hopkins MK (1987) Graveyards for historians. In: Hinard F (ed) La mort, les morts et l'au-delà dans le monde romain: actes du colloque de Caen, 20-22 novembre 1985. Universite de Caen Centre de Publications, Caen, p 113-126 
Hughes TP, Jackson JBC (1985) Population dynamics and life histories of foliaceous corals. Ecol Monogr 55:141-166

Jennings S, Kaiser MJ, Reynolds JD (2001) Marine fisheries ecology. Blackwell Publishing, Malden, MA

Jørgensen C, Holt RE (2013) Natural mortality: its ecology, how it shapes fish life histories, and why it may be increased by fishing. J Sea Res 75:8-18

Jull AJT, Burr GS, Hodgins G (2013) Radiocarbon dating, reservoir effects, and calibration. Quat Int 299:64-71

Keay A (1996) Accuracy of cementum age assignments for black bears. Calif Fish Game 81:113-121

Kidwell SM (1986) Taphonomic feedback in Miocene assemblages: testing the role of dead hardparts in benthic communities. Palaios 1:239-255

Kidwell SM (1991) The stratigraphy of shell concentrations. In: Allison PA, Briggs DEG (eds) Taphonomy: releasing the data locked in the fossil record. Plenum Press, New York, NY, p 212-290

Kidwell SM (2002) Time-averaged molluscan death assemblages: palimpsests of richness, snapshots of abundance. Geology 30:803-806

Kidwell SM (2013) Time-averaging and fidelity of modern death assemblages: building a taphonomic foundation for conservation palaeobiology. Palaeontology 56: 487-522

Kidwell SM, Rothfus STA (2010) The live, the dead, and the expected dead: variation in life span yields little bias of proportional abundances in bivalve death assemblages. Paleobiology 36:615-640

Kim SZ, Ainley DG, Pennycook J, Eastman JT (2011) Antarctic toothfish heads found along tide cracks of the McMurdo Ice Shelf. Antarct Sci 23:469-470

Klein RG, Bird DW (2016) Shellfishing and human evolution. J Anthropol Archaeol 44:198-205

Knutson DW, Buddemeier RW, Smith SV (1972) Coral chronometers: seasonal growth bands in reef corals. Science 177:270-272

Koppel B, Szabó K, Moore MW, Morwood MJ (2016) Untangling time-averaging in shell middens: defining temporal units using amino acid racemisation. J Archaeol Sci 7: 741-750

Koppel B, Szabó K, Moore MW, Morwood MJ (2017) Isolating downward displacement: the solutions and challenges of amino acid racemisation in shell midden archaeology. Quat Int 427:21-30

Kosnik MA, Kaufman DS, Hua Q (2013) Radiocarbon-calibrated multiple amino acid geochronology of Holocene molluscs from Bramble and Rib Reefs (Great Barrier Reef, Australia). Quat Geochronol 16:73-86

Kotlarczyk J, Jerzmańska A, Świdnicka E, Wiszniowska T (2006) A framework of ichthyofaunal ecostratygraphy of the Oligocene-early Miocene strata of the Polish outer Carpathian basin. Ann Soc Geol Pol 76:1-111

Krebs CJ (1999) Ecological methodology. Harper \& Row, New York, NY

Kambert O, Schlögl J, Ková M (2008) Middle Miocene toothed whale with Platanista-like teeth from the Vienna Basin (Western Carpathians, Slovakia). Neues Jahrb Geol Paläontol Abh 250:157-166

* Landman NH, Goolaerts S, Jagt JMW, Jagt-Jazykova EA, Machalski M, Yakobucci MM (2014) Ammonite extinction and nautilid survival at the end of the Cretaceous. Geology 42:707-710

Lanteri L, Schmitt A, Foti B, Naji S (2013) Testing inter-teeth variability in adult individual age-at-death estimate using cementochronology (TCA). Am J Phys Anthropol (Spec Iss) 150(S56):177

KLaptikhovsky V, Barrett C, Firmin C, Hollyman P and others (2016) A novel approach for estimation of the natural mortality of the common whelk, Buccinum undatum (L.) and role of hermit crabs in its shell turnover. Fish Res 183:146-154

Lee JZ, Tang F, Campbell C (1994) Infant and child mortality among the Qing nobility: implications for two types of positive check. Popul Stud (Camb) 48:395-411

Lettink M, Armstrong DP (2003) An introduction to using mark-recapture analysis for monitoring threatened species. Dept of Conservation (NZ) Tech Ser 28A:5-32

* Lieberman DE (1993) Life history variables preserved in dental cementum microstructure. Science 261:1162-1164

* Lieberman DE (1994) The biological basis for seasonal increments in dental cementum and their application to archaeological research. J Archaeol Sci 21:525-539

Lieberman DE, Meadow RH (1992) The biology of cementum increments (with an archaeological application). Mammal Rev 22:57-77

Lin CH, Girone A, Nolfe D (2015) Tortonian fish otoliths from turbiditic deposits in Northern Italy: taxonomic and stratigraphic significance. Geobios 48:249-261

* Lin CH, Girone A, Nolfe D (2016) Fish otolith assemblages from Recent NE Atlantic sea bottoms: a comparative study of palaeoecology. Palaeogeogr Palaeoclimatol Palaeoecol 446:98-107

Lin CH, Nolfe D, Steurbaut E, Girone A (2017a) Fish otoliths from the Lutetian of the Aquitaine Basin (SW France), a breakthrough in the knowledge of the European Eocene ichthyofaunal. J Syst Palaeontol 15:879-907

K Lin CH, Taviani B, Angeletti L, Girone A, Nolfe D (2017b) Fish otoliths in superficial sediments of the Mediterranean Sea. Palaeogeogr Palaeoclimatol Palaeoecol 471:134-143

K Lockyer C, Kinze C (2003) Status, ecology and life history of harbour porpoise (Phocoena phocoena) in Danish waters. NAMMCO Sci Publ 5:143-176

Logan A, Anderson IH (1991) Skeletal extension growth rate assessment in corals, using CT scan imagery. Bull Mar Sci 49:847-850

Luque SP, Ferguson SH (2010) Age structure, growth, mortality, and density of belugas (Delphinapterus leucas) in the Canadian Arctic: responses to environment? Polar Biol 33:163-178

*Mann R, Southworth M, Harding JM, Wesson JA (2009) Population studies of the native eastern oyster, Crassostrea virginica, (Gmelin, 1791) in the James river, Virginia, USA. J Shellfish Res 28:193-220

*Mannino MA, Thomas KD (2001) Intensive Mesolithic exploitation of coastal resources? Evidence from a shell deposit on the Isle of Portland (Southern England) for the impact of human foraging on intertidal rocky shore molluscs. J Archaeol Sci 28:1101-1114

*Mannino MA, Thomas KD (2002) Depletion of a resource? The impact of prehistoric human foraging on intertidal mollusc communities and its significance for human settlement, mobility and dispersal. World Archaeol 33: 452-474

*Mannino MA, Spiro BF, Thomas KD (2003) Sampling shells for seasonality: oxygen isotope analysis on shell carbonates of the inter-tidal gastropod Monodonta lineata (da Costa) from populations across its modern range and from a Mesolithic site in southern Britain. J Archaeol Sci 30:667-679 
McLoughlin R, Young PC, Martin RB, Parslow J (1991) The Australian scallop dredge: estimates of catching efficiency and associated indirect fishing mortality. Fish Res 11:1-24

Meesters EH, Wesseling I, Bak RPM (1996) Partial mortality in three species of reef-building corals and relation with colony morphology. Bull Mar Sci 58:838-852

Merrill AS, Posgay JA (1964) Estimating the natural mortality rate of the sea scallop (Placopecten magellanicus). ICNAF Res Bull 1:87-106

Morsan E, Zaidman PC (2008) Scale, dynamic and management in the harvesting of mussel in North Patagonia (Argentina). In: McManus NF, Bellinghouse DS (eds) Fisheries: management, economics and perspectives. Nova Science Publishers, New York, NY, p 171-197

Murakami M, Shimada C, Hikida Y, Hirano H (2015) New fossil remains from the Pliocene Koetoi Formation of northern Japan provide insights into growth rates and the vertebral evolution of porpoises. Acta Palaeontol Pol 60:97-111

* Murphy S, Spradlin TR, Mackey B, McVee J and others (2012) Age estimation, growth and age-related mortality of Mediterranean monk seals (Monachus monachus). Endang Species Res 16:149-163

Naidu KS (1988) Estimating mortality rates in the Iceland scallop, Chlamys islandica (Müller). J Shellfish Res 7: $61-71$

Newbrey MG, Ashworth AC (2004) A fossil record of colonization and response of lacustrine fish populations to climate change. Can J Fish Aquat Sci 61:1807-1816

Newbrey MG, Bozek M (2003) Age, growth, and mortality of Joffrichthys triangulpterus (Teleostei: Osteoglossidae) from the Paleocene Sentinel Butte Formation, North Dakota, USA. J Vertebrat Paleont 23:494-500

Newbrey MG, Wislon MVH, Ashworth AC (2007) Centrum growth patterns provide evidence for two small taxa of Hiodontidae in the Cretaceous Dinosaur Park formation. Can J Earth Sci 44:721-732

Newbrey MG, Wilson MVH, Ashworth AC (2008) Climate change and evolution of growth in Late Cretaceous to recent North American Esociformes. In: Arratia G, Schultze HP, Wilson MVH (eds) Mesozoic fishes 4 homology and phylogeny. Verlag Dr. Friedrich Pfeil, München, p 311-350

Newbrey MG, Siversson M, Cook TD, Fotheringham AM, Sanchez RL (2015) Vertebral morphology, dentition, age, growth, and ecology of the large lamniform shark Cardabiodon ricki. Acta Palaeontol Pol 60:877-897

Nielsen NH (2011) Age determination by aspartic acid racemization and growth layer groups, and survival rates of fin whales (Balaenoptera physalus) and harbour porpoises (Phocoena phocoena). MSc thesis, University of Copenhagen

O'Connor T (2000) The archaeology of animal bones. Sutton Publishing, Stroud

Olsen E, Sunde J (2002) Age determination of minke whales (Balaenoptera acutorostrata) using the aspartic acid racemization technique. Sarsia 87:1-8

Orensanz JM, Parma AM, Iribarne OO (1991) Population dynamics and management of natural stocks. In: Shumway SE (ed) Scallops: biology, ecology and aquaculture. Elsevier, Amsterdam, p 625-713

Ottestad P (1950) On age and growth of blue whales. Hvalråd $\mathrm{Skr}$ 33:67-72
Parsons-Hubbard KM, Callender WR, Powell EN, Brett CE, Walker SE, Raymond AL, Staff GM (1999) Rates of burial and disturbance of experimentally-deployed molluscs: implications for preservation potential. Palaios 14: 337-351

*Poirier C, Sauriau PG, Chaumillon E, Bertin X (2010) Influence of hydro-sedimentary factors on mollusc death assemblages in a temperate mixed tide-and-wave dominated coastal environment: implications for the fossil record. Cont Shelf Res 30:1876-1890

* Powell J, Collins MJ, Cussens J, Macleod N, Penkman KEH (2013) Results from an amino acid racemization inter-laboratory proficiency study; design and performance evaluation. Quat Geochronol 16:183-197

* Quijón PA, Grassle JP, Rosario JM (2007) Naticid snail predation on early post-settlement surfclams (Spisula solidissima) on the inner continental shelf of New Jersey, USA. Mar Biol 150:873-882

Quinn T, Deriso RB (1999) Quantitative fish dynamics. Oxford University Press, New York, NY

Reimer PJ (2014) Marine or estuarine radiocarbon reservoir corrections for mollusks? A case study from a medieval site in the south of England. J Archaeol Sci 49:142-146

* Rick TC, Lockwood R (2013) Integrating paleobiology, archeology, and history to inform biological conservation. Conserv Biol 27:45-54

* Rick TC, Reeder-Myers LA, Hofman CA, Breirburg D and others (2016) Millennial-scale sustainability of the Chesapeake Bay native American oyster fishery. Proc Natl Acad Sci USA 113:6568-6573

* Ridgway ID, Richardson CA, Austad SN (2011) Maximum shell size, growth rate, and maturation age correlate with longevity in bivalve molluscs. J Gerontol A Biol Sci Med Sci 66A:183-190

* Rilov G, Benayahu Y, Gasith A (2001) Low abundance and skewed population structure of the whelk Stramonita haemastoma along the Israeli Mediterranean coast. Mar Ecol Prog Ser 218:189-202

* Roark EB, Guilderson TP, Dunbar RB, Ingram BL (2006) Radiocarbon-based ages and growth rates of Hawaiian deep-sea corals. Mar Ecol Prog Ser 327:1-14

Roark EB, Guilderson TP, Dunbar RB, Fallon SJ, Mucciarone DA (2009) Extreme longevity in proteinaceous deep-sea corals. Proc Natl Acad Sci USA 106:5204-5208

Robbins J, Jones M, Matisoo-Smith E (2001) Amino acid racemization dating in New Zealand: an overview and bibliography. Auckland University, Auckland

Roberts D (1978) Variation in coyote age determination from annuli in different teeth. J Wildl Manag 42:454-456

Roe HSJ (1968) Seasonal formation of laminae in the ear plug of the fin whale. Discov Rep 35:1-29

Roff G, Zhao JX, Mumby PJ (2015) Decadal-scale rates of reef erosion following El Niño-related mass coral mortality. Glob Change Biol 21:4415-4424

Kosa C, Zeh J, George JC, Botta O, Zauscher M, Bada J, O'Hara TM (2013) Age estimates based on aspartic acid racemization for bowhead whales (Balaena mysticetus) harvested in 1998-2000 and the relationship between racemization rate and body temperature. Mar Mamm Sci 29:424-445

Ruud JT, Jonsgård Å (1950) Age studies on blue whales taken in Antarctic seasons 1945-46, 1946-47 and 1947-48. Hvalråd Skr 33:5-66

Santarelli L, Gros P (1985) Age and growth of the whelk Buccinum undatum L. (Gastropoda: Prosobranchia) using 
stable isotopes of the shell and operculum striae. Oceanol Acta 8:221-229

Scheidel W (2001) Roman age structure: evidence and models. J Roman Stud 91:1-26

Scheidel W (2015) Death and the city: ancient Rome and beyond. Princeton/Stanford Working Papers in Classics, doi:10.13140/RG.2.1.1408.4000

Schwarzhans W (2003) Fish otoliths from the Paleocene of Denmark. Geol Surv Den Greenl Bull 2:94

Sebens KP (1987) The ecology of indeterminate growth in animals. Annu Rev Ecol Evol Syst 18:371-407

* Simonson AE, Lockwood R, Wehmiller JF (2013) Three approaches to radiocarbon calibration of amino acid racemization in Mulinia lateralis from the Holocene of the Chesapeake Bay, USA. Quat Geochronol 16:62-72

Steele TE (2003) Using mortality profiles to infer behaviour in the fossil records. J Mammal 84:418-430

Stiner M (1990) The use of mortality patterns in archaeological studies of hominid predatory adaptations. J Anthropol Archaeol 9:305-351

Sukhovskaya LI, Klevezal GA, Borisov VI, Lagerev SJ (1985) Use of bone layers to determine age in minke whales. Acta Theriol (Warsz) 30:275-286

Supriharyono S (2004) Growth rates of the massive coral Porites lutea Edward and Haime, on the coast of Bontang, East Kalimantan, Indonesia. J Coastal Dev 7:143-155

Swithinbank CWM, Darby DG, Wohlschlag DE (1961) Faunal remains on the Antarctic ice shelf. Science 133:764-766

Thomas KD (2015) Molluscs emergent, Part I: themes and trends in the scientific investigation of mollusc shells as resources for archaeological research. J Archaeol Res 56: 133-140

Trumble SJ, Robinson EM, Berman-Kowalewski M, Potter CW and others (2013) Blue whale earplug reveals lifetime contaminant exposure and hormone profiles. Proc Natl Acad Sci USA 110:16922-16926

*Volstad JH, Dew J, Tarnowski M (2008) Estimation of annual mortality rates for eastern oysters (Crassostrea virginica) in Chesapeake Bay based on box counts and application of those rates to project population growth of C. virginica and C. ariakensis. J Shellfish Res 27:525-533

Editorial responsibility: Stylianos Somarakis, Heraklion, Greece
Walker SE (1988) Taphonomic significance of hermit crabs (Anomura: Paguroidea): epifaunal hermit crab-infaunal gastropod example. Palaeogeogr Palaeoclimatol Palaeoecol 63:45-71

*Wehmiller JF (2013) Interlaboratory comparison of amino acid enantiomeric ratios in Pleistocene fossils. Quat Geochronol 16:173-182

*Weissberger EJ, Grassle JP (2003) Settlement, first-year growth, and mortality of surfclams, Spisula solidissima. Estuar Coast Shelf Sci 56:669-684

Wendt PH, Knott DM, Van Dolah RF (1989) Community structure of the sessile biota on five artificial reefs of different ages. Bull Mar Sci 44:1106-1122

Wierzbowski H (2013) Life span and growth rate of Middle Jurassic mesohibolitid belemnites deduced from rostrum microincrements. Volumina Jurassica 11:1-18

*Wierzbowski H, Joachimski MM (2009) Stable isotopes, elemental distribution, and growth rings of belemnopsid belemnite rostra: proxies for belemnite life habitat. Palaios 24:377-386

*Wilson AE, Newbrey MG, Brinkman DB, Neuman AG (2013) Age and growth in Myledaphus bipartitus, a Late Cretaceous freshwater guitarfish from Alberta, Canada. Can J Earth Sci 50:930-944

*Wolverton S, Dombrosky J, Lyman RL (2016) Practical significance: ordinal scale data and effect size in zooarchaeology. Int J Osteoarchaeol 26:255-265

*Woods R (2007) Ancient and early modern mortality: experience and understanding. Econ Hist Rev 60: 373-399

Woydack A, Morales-Nin B (2001) Growth patterns and biological information in fossil fish otoliths. Paleobiology 27 : 369-378

K Yanes Y, Kowalewski M, Romanek CS (2012) Seasonal variation in ecological and taphonomic processes recorded in shelly death assemblages. Palaios 27:373-385

Khao MX, Yu KF, Zhang QM, Shi Q, Roff G (2014) Age structure of massive Porites lutea corals at Luhuitou fringing reef (northern South China Sea) indicates recovery following severe anthropogenic disturbance. Coral Reefs 33:39-44

Submitted: January 23, 2017; Accepted: July 14, 2017 Proofs received from author(s): October 1, 2017 